\title{
任意方位角を有する平面波斜闭に射対する \\ 2 次元構造物の応答解析

\author{
RESPONSE ANALYSIS OF 2-D STRUCTURE \\ SUBJECTED TO OBLIQUELY INCIDENT WAVES \\ WITH ARBITRARY HORIZONTAL ANGLES
}

\author{
永野正行*, 源栄 正 人** \\ Masayuki NAGANO and Masato MOTOSAKA
}

\begin{abstract}
In the response analysis of a two-dimensional structure, plane body waves acting at an arbitrary angle with respect to the axis of a two-dimensional section induce a three-dimensional response with constant wave velocity normal to a twodimensional section. Hyperelements and finite elements of moving loads are used for three-dimensional response analyses of two-dimensional structures subjected to an obliquely incident wave with an arbitrary horizontal angle. As examples, three-dimensional wave propagation of a sedimentary basin and three-dimensional responses of twin tunnels embedded in a uniform half-space are investigated and their response characteristics are discussed.
\end{abstract}

\author{
Keywords : hyperelement, finite element, two-dimensional structure, \\ three-dimensional response, obliquely incident wave, horizontally incident angle \\ ハイパーエレメント、有限要素、2 次元構造物、3 次元応答、斜め入射波、方位角
}

\section{1.はじめに}

奥行き方向に無限に続く同一断面を有する不整形地盤 やトンネル状の地下構造物などの 2 次元構造物に対する 平面波入射問題において、Fig.1に示すように入射波の進 行方向が 2 次元断面と直交せず、ある角度（この角度 $\theta_{\mathrm{k}}$ を以降、方位角と記す。）をもって入射するとき、奥行 き方向には一定の速度で伝播する波動が現れる。この場 合の忘答はSH波、ラブ波による面外波動、P・SV波、レ イリー波による面内波動が連成した 3 次元挙動を示す。 このような 3 次元問題に対しては、移動荷重に対するグ リーン関数 (Moving Green's Function、以降MGF と記 す。）や動的剛性等を用いることにより、モデル上は 1 節点 3 自由度を有するものの、見かけ上 2 次元問題とし て効率的に解析することができる。

この 3 次元応答問題に対し、本論文ではKauselら"に よって提案された解析手法を発展させ、移動荷重に対し て定式化したhyperelement剛性を用いた解析手法を示す。 この手法の特徵として、無限積分の形となっているMGF
の計算が不要であること、同一成層領域では水平方向に は厳密解と同じ波動関数を用いているため水平方向に有 限要素法のような要素分割を行う必要がなく、有限要素 解析に比べ少ない自由度でかつ高精度の解析が可能であ り、大領域構造の解析に有効であることが挙げられる。

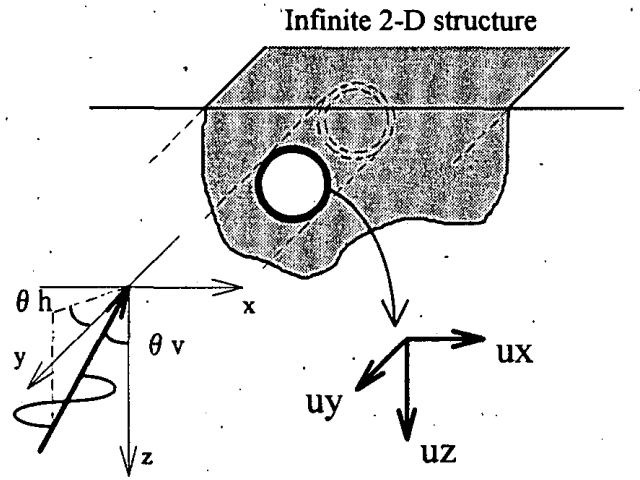

Fig.1 Three-dimensional response of two-dimensional structure
* 鹿島小堀研究室 研究貝

** 鹿島小堀研究室 主管研究員・工博
Kobori Research Complex, Kajima Corporation

Kobori Research Complex, Kajima Corporation, Dr. Eng. 
また本論文では鉛直境界で区切られた比較的大きな領 域のモデル化を対象としているhyperelement手法とともに、 鉛直境界以外の不整形境界を有する局所的な構造一の応 用も考え、移動荷重に対して定式化した有限要素を用い hyperelementと結合したハイブリッド手法を、任意方位角 を有する平面波斜め入射に対する 2 次元構造の 3 次元応 答問題に適用する。これは現在多くの構造物、地盤の地 震応答解析において用いられている、底面・粘性境界、 側面・エネルギー伝達境界とした 2 次元FEM解析手法に 対し、任意方位角を有する斜め入射波に対する 3 次元応 答解析へと発展可能な手法としても有用なものである。 これらの手法は当然のことながら、車両等の移動加振源 に対する応答解析手法としても用いることも可能である。

この 3 次元問題に対する既往の研究には、固有関数展 開法を用いて半無限地盤中の埋設管の 3 次元忘答解析を 行ったWongら 2)の研究、半無限成層構造に対するMGFを 用いて、間接境界要素法により、任意方位角を有する平 面実体波斜め入射に対する円形谷や埋設トンネルの态答 解析を実施したLuco ${ }^{334)}$ の研究を始め、遠方境界には半 無限弹性体に対するMGFを内部領域には移動荷重に対す る有限要素を用いた結合解析を、神積谷や埋め戻し土中 のパイプラインの実体波入射解析に適用したKhair $5^{5)}$ 、 Liu ${ }^{6)}$ の研究などがある。これらの移動荷重問題に関連 した研究として、福和らは全無限地盤に対するMGF ${ }^{7}$ と 薄層要素を用いて誘導したMGF8)を、源栄ら9は成層半無 限地盤におけるMGFを示し、それぞれその基本的特性を 示している。また移動荷重に対する有限要素法を用いた 3 次元解析はHwangら10)により適用され、固定基盤での 位相差入力により矩形トンネルの答解析を行っている。 またHanazatoら ${ }^{11)}$ はトラック等の振動による地盤応答を、 移動振源に対して定式化した有限要素法とエネルギー伝 達境界を用いて解析している。しかしこれらは地盤の半 無限性を考慮した任意方位角、入射角を有する入射波に 対する解析までは行っていない。

本研究では、最初にhyperelement手法を用いた大領域構 造の解析例として、2 次元形状の堆積谷に寒体波が斜め 入射するときの波動伝播解析を実施し、入射波が鉛直軸 に対する入射角のみでなく、現在まであまり行われてい ない方位角を有するケースでの 3 次元波動伝播特性を検 討する。次にhyperelement手法と有限要素との結合手法を 用いた例として、半無限地盤中に建設される双設トンネ ル構造物の态答計算例を示し、入射角、方位角入射がそ の忘答に与える影響を単独トンネルの場合と比較して調 ベる。

\section{2. 解析手法の概要}

（1）移動荷重に対するhyperelementの定式化

3 次元弾性体の支配方程式は物体力を無視すると次式 で与えられる。

$$
(\lambda+\mu) u_{j, U}+\mu u_{1, y}=-\omega^{2} \rho u_{1}, I=x, y, z
$$

ここで $\lambda 、 \mu$ は地盤のLamé定数、 $\rho$ は密度、 $\omega$ は円振動 数で、時間に関する定常状態を $\mathrm{e}^{\text {iot }}$ と仮定している。(1) 式をx,yに関してフーリエ変換後、波数領域における変位 場のx方向成分とy方向成分をRadial方向成分と Transverse 方向成分一変換 L、P-SV成分 $\left\{U_{1}, U_{2}\right\}$ とSH成分 $\left\{U_{3}\right\}$ の変 位場に分離する。

$$
\left\{\begin{array}{l}
U_{x} \\
U_{y} \\
U_{z}
\end{array}\right\}=\left[\begin{array}{ccc}
i_{x} / k & 0 & i k_{y} / k \\
i k_{y} / k & 0 & -i k_{x} / k \\
0 & 1 & 0
\end{array}\right]\left\{\begin{array}{l}
U_{1} \\
U_{2} \\
U_{3}
\end{array}\right\}
$$

ここで $\mathrm{U}_{\mathrm{I}}\left(\mathrm{k}_{\mathrm{x}}, \mathrm{k}_{\mathrm{y}}, \mathrm{z}, \omega\right), \mathrm{I}=\mathrm{x}, \mathrm{y}, \mathrm{z}$ はフーリエ変換領域での值を 示し、 $k_{x}$ はx方向の波数、 $k_{y}$ はy方向の波数、 $k^{2}=k_{x}^{2}+k_{y}^{2}$ である。また $\mathrm{i}=\sqrt{-1}$ である。変換された各方程式に対し $\mathrm{z}$ 方向にガラーキン法を適用し、層内で変位を線形仮定 し離散化後、剛性の重ね合わせをすると次式の一般化レ イリー波方程式と一般化ラブ波方程式が得られる。各方 程式の大きさは半無限層を含む地盤分割数Nとなる。各 マトリックスの内容はAPPENDIX-Iに示されている。

$$
\begin{aligned}
& \left(k^{2}\left[A_{p}\right]+\left[E_{s}\right]+\left[E_{s}^{\prime}\right]\right)\left\{U_{1}\right\}-k[B]^{\mathrm{T}}\left\{U_{2}\right\}=\{0\} \\
& \left(k^{2}\left[A_{s}\right]+\left[E_{p}\right]+\left[E_{p}^{\prime}\right]\right)\left\{U_{2}\right\}-k[B]\left\{U_{1}\right\}=\{0\} \\
& \left(k^{2}\left[A_{s}\right]+\left[E_{s}\right]+\left[E_{s}^{\prime}\right]\right)\left\{U_{3}\right\}=\{0\}
\end{aligned}
$$

ここで $\left[\mathrm{E}_{\mathrm{S(P)}}^{\prime}\right]$ は鉛直方向における地盤の半無限効果を表 現するため、底面位置に設定する粘性境界項である。ま た下方地盤の半無限性を表現するものとして他にparaxial 近似やdoubly asymptotic近似 ${ }^{12)}$ が用いられる場合もある。 次に波数kに関する代数方程式となっている(3a)(3b)式の $\mathrm{P} \cdot \mathrm{SV}$ 波に関する $4 \mathrm{~N}$ 次元（地盤物性により $2 \mathrm{~N}$ 次元に縮約 可能）の固有值解析、(3c)式のSH波に関するN次元の固 有值解析を行う。ここで得られた固有值、固有モードを (2)式により直交座標系に変換し、 $\mathrm{k}_{\mathrm{y}}$ を入射角等により決 定されるy方向の波数 $\mathrm{k}_{\mathrm{y}}^{0}$ に固定し、 $\mathrm{k}_{\mathrm{x}}$ に関しxの正負進行 方向に分解する。得られた $\mathrm{x}$ 方向のs次固有波数を $\mathrm{k}_{\mathrm{L}(\mathrm{R}) \mathrm{s}}^{+(-)} 、 \mathrm{~s}$ 次固有モードを $\left\{\mathrm{V}_{\mathrm{L}(\mathrm{R})}^{+(-)}\right\}$，とし、各モードに対する刺激係数 を $\alpha_{\mathrm{L}(\mathrm{R}) \text {, }}^{+()}$とす。上添字十、一はx方向に関し正負進行 モードを、下添字L、Rは(3c)式のラブ波方程式、(3a)(3b) 式のレイリー波方程式からの寄与を示し、それぞれ $=\mathrm{N}$ 、 2N組を有する。またこれらをまとめた形として、正負方 向の固有波数マトリックス（対角項のみ）を[ $\left.\mathrm{k}_{\mathrm{x}}^{+}\right],\left[\mathrm{k}_{\mathrm{x}}^{-}\right]$、 モードマトリックスを $\left[\mathrm{V}^{+}\right],\left[\mathrm{V}^{-}\right]$、刺激係数ベクトル（末 知係数)を $\left\{\alpha^{+}\right\},\left\{\alpha^{-}\right\}$とする。これらは $3 \mathrm{~N}$ 次正方行列もし くは3N次元ベクトルとなる。

2 次元の不整形地盤がFig.2に示すように、いくつかの 層序の異なる鉛直境界を有する成層地盤領域でモデル化

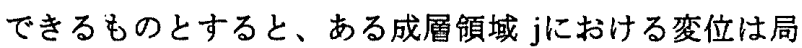


所座標系引により次式のように示される。 $\left\{{ }^{j} \mathrm{U}\left({ }^{\mathrm{i}} \xi\right)\right\}=\left\{{ }^{\mathrm{j}} \mathrm{U}^{\mathrm{i}}\left({ }^{\mathrm{j}} \xi\right)\right\}$

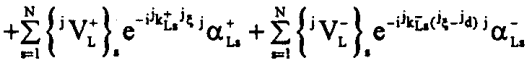

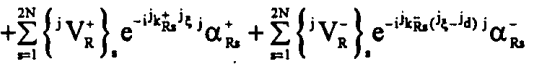

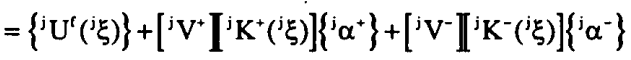

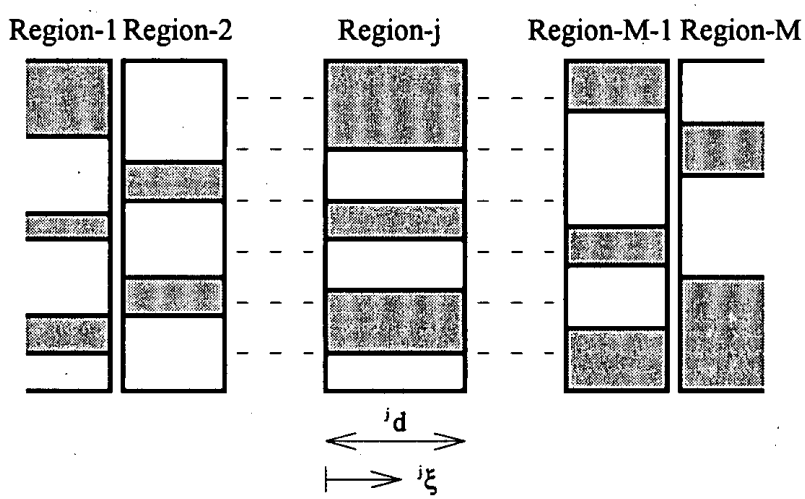

Fig.2 Irregularly layered media comprising several regions with horizontally flat layers

ここで

$$
\left[{ }^{j} K^{+}\left({ }^{j} \xi\right)\right]=\left[\begin{array}{lll}
\ddots & & 0 \\
& \mathrm{e}^{-k_{x}^{+} j_{\xi}} & \\
0 & & \ddots
\end{array}\right],\left[{ }^{j} \mathrm{~K}^{-}\left({ }^{\mathrm{j} \xi} \xi\right)\right]=\left[\begin{array}{lll}
\ddots & & 0 \\
& \mathrm{e}^{\left.-k_{x}^{-} j_{\xi}-j_{d}\right)} & \\
0 & & \ddots
\end{array}\right]
$$

である。'd は領域 jの幅である。また $\left\{{ }^{\mathrm{i}} \mathrm{U}^{\mathrm{f}} \mathrm{(}\right.$ ( $\left.)\right\}$ は入射場に おける変位を示し、 $\mathrm{e}^{-\mathrm{k}_{\mathrm{k}}^{0 \mathrm{k}}}$ を含む形となる。ここで $\mathbf{k}_{\mathrm{x}}^{0}$ は $\mathbf{k}_{\mathrm{y}}^{0}$ と同様に入射角、方位角より決定される $\mathrm{x}$ 方向の波数で ある。同様に節点力は次式で表される（マトリックスの 内容はAPPENDIX-II 参照)。

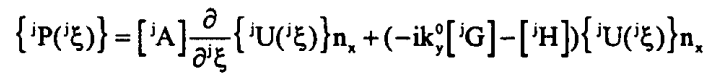

ここで $\mathrm{n}_{\mathrm{x}}$ はx=一定面に対する法線ベクトル係数であり、 左右鉛直境界に対してそれぞれ-1，1となる。(4)(5)式に 左右境界座標（ ${ }^{j} \xi=0,{ }^{j} \mathrm{~d}$ ） を代入した後、刺激係数べク トル $\left\{{ }^{\mathrm{j}}{ }^{+}\right\},\left\{{ }^{\mathrm{j}} \alpha^{-}\right\}$を消去することにより、領域 $\mathrm{j}$ の左右境界 における節点力ベクトル $\left\{{ }^{j} \mathrm{P}_{\mathrm{LRR} R}\right\}$ と変位ベクトル $\left\{{ }^{\mathrm{j}} \mathrm{U}_{\mathrm{LRR}}\right\}$ と の関係が次式のように得られる。

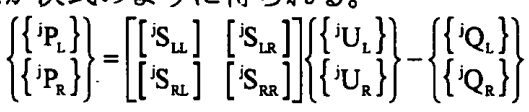

式中、下添字L,Rは左右境界の自由度に対応する量を示

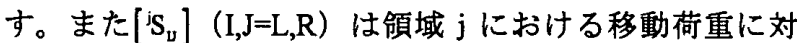
する hyperelementマトリックス、また $\left\{{ }^{i} \mathrm{Q}_{\mathrm{J}}\right\} \quad(\mathrm{J}=\mathrm{L}, \mathrm{R})$ はサ ブストラクチャー法における左右境界端のドライビング フォース・ベクトルに相当し、それぞれ以下のように示 される。

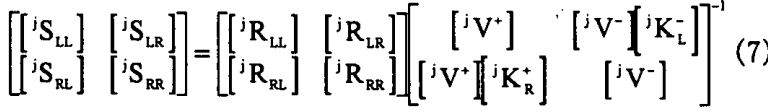

$$
\begin{aligned}
& {\left[{ }^{\mathrm{i}} \mathrm{R}_{\mathrm{LL}}\right]=\mathrm{i}\left[{ }^{\mathrm{i}} \mathrm{A}\right]\left[{ }^{[} \mathrm{V}^{+}\right]\left[{ }^{\mathrm{i}} \mathbf{k}_{\mathrm{x}}^{+}\right]+\left(\mathrm{ik}_{\mathrm{y}}^{\mathrm{o}}\left[{ }^{\mathrm{i}} \mathrm{G}\right]+\left[{ }^{\mathrm{j}} \mathrm{H}\right]\right)\left[{ }^{\mathrm{j}} \mathrm{V}^{+}\right]}
\end{aligned}
$$

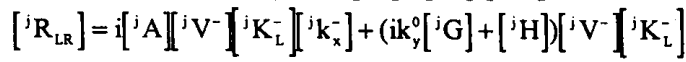

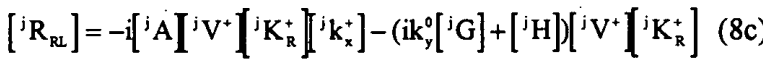

$$
\begin{aligned}
& {\left[{ }^{j} R_{R R}\right]=-i\left[{ }^{j} A\right]\left[{ }^{j} V^{-}\right]\left[{ }^{j} \mathbf{k}_{x}^{-}\right]-\left(i \mathbf{k}_{y}^{0}\left[{ }^{i} \mathrm{G}\right]+\left[{ }^{j} \mathrm{H}\right]\right)\left[{ }^{j} \mathrm{~V}^{-}\right]}
\end{aligned}
$$

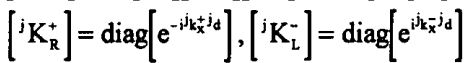

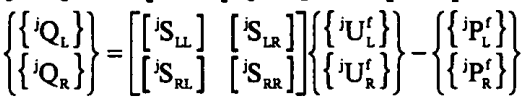

ここで $\left\{{ }^{j} \mathrm{U}_{1}^{t}\right\},\left\{{ }^{j} \mathrm{P}_{1}^{t}\right\}(\mathrm{I}=\mathrm{L}, \mathrm{R})$ は左右鉛直境界における自由地 盤場の変位と節点力である。(6)式を成層領域 1 から MK

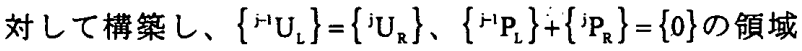
間の鉛直境界に対する適合条件を適用することにより解 くべき全体方程式が得られる。

$\left[\left[\mathrm{S}_{\mathrm{RR}}\right]+\left[{ }^{2} \mathrm{~S}_{\mathrm{U}}\right]\left[{ }^{2} \mathrm{~S}_{\mathrm{LR}}\right] \quad \cdots\right]\{\mathrm{U}\}=\left\{\left\{{ }^{1} \mathrm{Q}_{\mathrm{R}}\right\}+\left\{{ }^{2} \mathrm{Q}_{\mathrm{L}}\right\}\right\}$

$\left[\cdots\left[{ }^{j-1} S_{R L}\right]\left[{ }^{j-1} S_{R R}\right]+\left[{ }^{i} S_{L}\right]\left[{ }^{i} S_{L R}\right] \cdots\right]\{U\}=\left\{\left\{{ }^{j-1} Q_{R}\right\}+\left\{{ }^{i} Q_{L}\right\}\right\}$

$\left[\cdots\left[{ }^{M-1} S_{R L}\right]\left[{ }^{M-1} S_{R R}\right]+\left[{ }^{M} S_{L}\right]\right]\{U\}=\left\{\left\{{ }^{M-1} Q_{R}\right\}+\left\{{ }^{M} Q_{L}\right\}\right\}$

ここで左端、右端領域境界に付加する剛性 $\left[{ }^{2} \mathrm{~S}_{\mathrm{RR}}\right]\left[{ }^{\mathrm{M}} \mathrm{S}_{\mathrm{LL}}\right]$ は いわゆるエネルギー伝達境界マトリックスに相当する。 (10)式で鉛直境界における変位が得られると、(4)式より 各領域の刺激係数べクトルが算定され、任意の点におけ る変位を求めることができる。

\section{（2）平面波入射時の自由地盤の忘答}

3 次元成層地盤の水平平面で軸に $\theta_{\mathrm{h}}$ （方位角）、平面 波入射面 $x^{\prime} y^{\prime}$ で $z$ 軸に $\theta_{v}$ （入射角）の成す角を持って入射 する自由地盤場における応答変位やx,y方向の波数を求め る。Fig.3に示すようにx、y軸を方位角に対応した $x^{\prime} 、 y^{\prime}$ 軸 に変換し、この軸における変位を表すと、

$$
\left\{\begin{array}{lll}
U_{x}^{t} & U_{y}^{t} & U_{z}^{i}
\end{array}\right\}^{T}=e^{-i x_{x} \times}\left\{\begin{array}{lll}
U_{1}^{i} & U_{3}^{t} & U_{2}^{t}
\end{array}\right\}^{\mathrm{T}}
$$

ここで、

$$
\begin{aligned}
& \mathbf{k}_{\mathrm{x}^{\prime}}=\frac{\omega}{\mathrm{V}_{\mathrm{SN}}} \sin \theta_{\mathrm{v}} \quad \text { (S波入射時) } \\
& \mathbf{k}_{\mathrm{x}^{\prime}}=\frac{\omega}{\mathrm{V}_{\mathrm{PN}}} \sin \theta_{\mathrm{v}} \quad \text { (P波入射時) }
\end{aligned}
$$

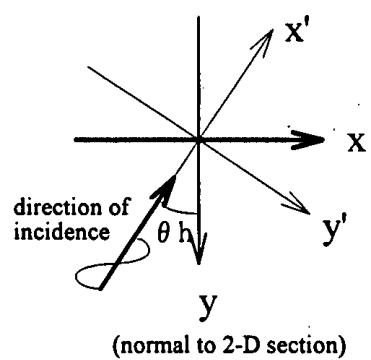

(a) Horizontal angle of obliquely incident wave

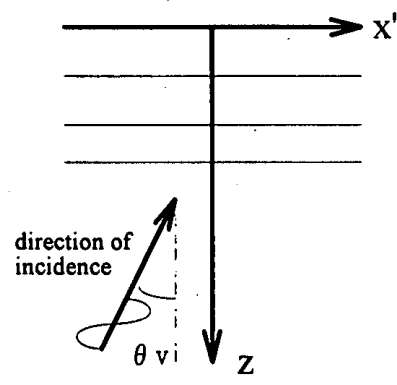

(b) Vertical angle of obliquely incident wave
Fig.3 Horizontal and vertical angles of obliquely incident wave

$\mathrm{U}_{1}^{\mathrm{t}}, \mathrm{U}_{2}^{\mathrm{t}}$ はP $\cdot \mathrm{SV}$ 入射時に、 $\mathrm{U}_{3}^{\mathrm{t}}$ はSH波入射時に発生し、2 次元の薄層要素マトリックスに入射角に忘じたインピー ダンスマトリックス、ドライビングフォースを薄層領域 底面に考慮することにより得られる（APPENDIX-III参 照）。また下添字Nは入射波を規定する最下層（半無限 層)での諸元を示す。 $x, y, z$ 軸での自由地盤応答は、 


$$
\begin{aligned}
& \left\{\begin{array}{l}
x^{\prime} \\
y^{\prime} \\
z
\end{array}\right\}=\left[\begin{array}{ccc}
\sin \theta_{b} & -\cos \theta_{b} & 0 \\
\cos \theta_{b} & \sin \theta_{b} & 0 \\
0 & 0 & 1
\end{array}\right]\left\{\begin{array}{l}
x \\
y \\
z
\end{array}\right\}=[T]^{\top}\left\{\begin{array}{l}
x \\
y \\
z
\end{array}\right\} \\
& \left\{\begin{array}{l}
U_{x}^{t} \\
U_{y}^{u} \\
U_{z}^{t}
\end{array}\right\}=[T]\left\{\begin{array}{l}
U_{x}^{i} \\
U_{y}^{u} \\
U_{z}^{u}
\end{array}\right\}
\end{aligned}
$$

の関係を考虐すると次式のように示される。

$$
\left\{\begin{array}{l}
\mathrm{U}_{\mathrm{x}}^{\mathrm{s}} \\
\mathrm{U}_{\mathrm{y}}^{t} \\
\mathrm{U}_{\mathrm{z}}^{t}
\end{array}\right\}=[\mathrm{T}\}\left[\begin{array}{c}
\mathrm{U}_{1}^{t} \\
\mathrm{U}_{3}^{t} \\
\mathrm{U}_{z}^{t}
\end{array}\right\} \exp \left(-\mathbf{i} \mathbf{k}_{\mathrm{x}}^{0} \mathrm{x}-\mathrm{ik} \mathrm{k}_{\mathrm{y}}^{0} \mathrm{y}\right)
$$

ここで、

$$
\mathbf{k}_{\mathrm{x}}^{0}=\mathbf{k}_{\mathrm{x}} \sin \theta_{\mathrm{h}}, \mathbf{k}_{\mathrm{y}}^{0}=-\mathbf{k}_{\mathrm{x}} \cos \theta_{\mathrm{h}}
$$

$\mathbf{k}_{y}^{0}=\omega / \mathrm{c}_{y}^{0}$ とすると、 $c_{y}^{0}=-V_{s(p) N} /\left(\sin \theta_{v} \cos \theta_{\mathrm{h}}\right)$ はy方向の見 かけ上の波動伝播速度を示す。実体波入射時には振動数 に関わらず c は一定となり、これがhyperelementマトリッ クス等を算定するときの移動荷重の速度に対応する。ま た切り欠き力として表される自由地盤の節点力 $\left\{\mathrm{P}^{t}\right\}$ は、

(13)式により得られた自由地盤応答を(5)式に代入するこ とにより得られる。以上により得られた $\mathbf{k}_{x}^{0}, \mathbf{k}_{y}^{0},\left\{\mathrm{U}^{t}\right\},\left\{\mathrm{P}^{t}\right\}$ を(6)式の hyperelementマトリックスやドライビング フォースベクトルの算定に用いる。

\section{（3）移動荷重に対する有限要素剛性の定式化}

移動荷重に対する有限要素剛性の誘導 通常の有限要素剛性と同様であるが、奥行き方向（y方 向）に関してはフーリエ変換を行うので、 $x 、 z$ 平面上の 3 自由度を有する節点に対し離散化を行う。例えば 4 角 形 4 節点アイソパラメトリック要素に対しては、仮想仕 事の原理を用いることにより剛性マトリックスは最終的 に次のような形で示される。

$$
\left[\mathrm{K}_{\mathrm{F}}\right]=\int_{-1}^{1} \int_{--1}^{1}\left[\mathrm{~B}_{\mathrm{F}}^{*}\right]^{\mathrm{T}}\left[\mathrm{D}_{\mathrm{F}}\left[\mathrm{B}_{\mathrm{F}}\right] \operatorname{det}[\mathrm{J}] \mathrm{dnd} \boldsymbol{\mathrm { s }}\right.
$$

ここで $\left[\mathrm{D}_{\mathrm{F}}\right],\left[\mathrm{B}_{\mathrm{F}}\right]$ はそれぞれ忘カー歪マトリックス、歪一 節点変位マトリックスで、 $6 \times 6$ 行列、 $6 \times 12$ 行列となっ ている。*は共役複素マトリックスを、また[J]はヤコビ アンマトリックスを示す。[ $\left.\mathrm{B}_{\mathrm{g}}\right]$ はy方向の波数 $\mathrm{k}_{\mathrm{y}}^{0}$ を含む 形となる (APPENDIX-IV参照)。(15)式はGauss-Legendreの 求積法などの数值積分により算定する。質量マトリック スについても同様に求める。

（4）有限要素領域底面における半無限地盤のモデル化 ある鉛直境界で区切られた不整形領域を、有限要素と hyperelement とのハイブリッドで表現する場合は、 hyperelement左右境界におけるドライビングフォースで外 力を規定すればよいが、有限要素のみで不整形領域をモ デル化する場合、領域底面に半無限性を表現するために 粘性境界と平面波入射に伴うドライビングフォースを考 虑する必要がある。このときの領域底面における表面力 は次式のように表される。

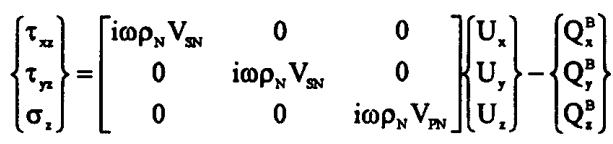

ここで $\mathrm{Q}_{1}^{\mathrm{a}}(\mathrm{I}=\mathrm{x}, \mathrm{y}, \mathrm{z})$ は領域底面におけるドライビング フォースで次のように表される。

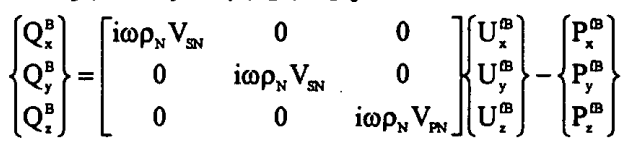

ここで $\mathrm{U}_{1}^{\mathrm{B}}, \mathrm{P}_{1}^{\mathrm{B}}(\mathrm{I}=\mathrm{x}, \mathrm{y}, \mathrm{z})$ は領域底面における自由地盤場での 变位とz面に関する表面力であり、前述の自由地盤の応 答計算より求められる。(16)式を離散化する事により、 有限要素領域下に考慮する粘性境界とドライビング フォースが得られる。

\section{3. 解析手法の検証}

任意方位角を有する平面波斜め入射に対する 2 次元構 造系の解析手法として定式化した移動荷重に対する hyperelementと有限要素を検証するために、Fig.4(a)に示 すような半径 $\mathrm{a} の 円$ 形谷に入射角、方位角を伴って入射 するSV波に対する応答結果を、MGFを用いて間接境界要 素法で計算を行ったLucoらによる解析結果 ${ }^{3}$ と比較する。

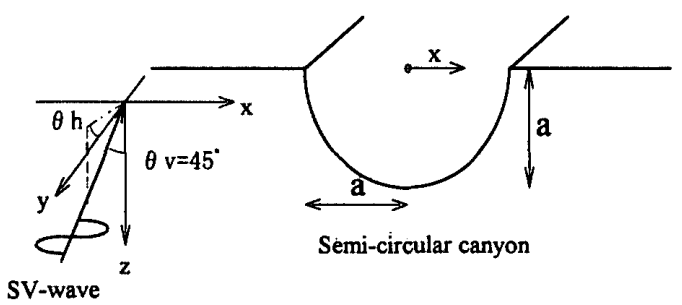

(a) Semi-circular canyon subjected to obliquely incident SV-waves

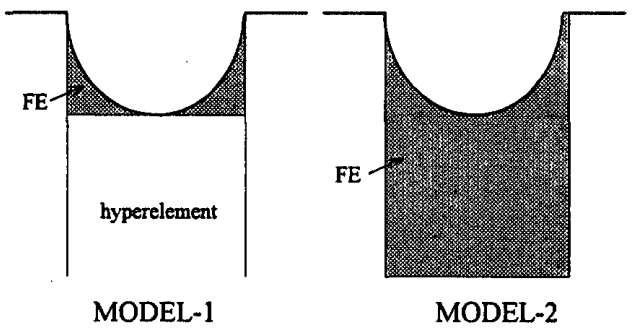

(b) Modeling of Semi-circular canyon

Fig.4 Analytical model for verification of the proposed model

Fig.4(b)に示すように、検証用モデルとして不整形㴿域 をhyperelementと有限要素の結合により表した解析モデル （MODEL-1）、有限要素のみにより表した解析モデル (MODEL-2)の 2 つを用いる。いずれも左右の境界では移 動荷重に対するhyperelement、すなわち移動荷重に対する エネルギー伝達境界が仮定されている。水平方向は2aの 領域を $\mathrm{a} / 5$ 幅で分割し、深さ方向は底面まで $4 \mathrm{a}$ の領域を $\mathrm{a} / 5$ 幅の要素20層でモデル化している。Fig.5に $\eta=\omega V_{s} / \mathrm{a}=1.0$ 、 
ポアソン比 $1 / 3 、 \theta_{v}=45^{\circ} 、 \theta_{h}=1^{\circ} 、 45^{\circ} 、 90^{\circ} \quad\left(\theta_{h}=90^{\circ}\right.$ は 2 次 元面内問題）の解析ケースに対して半円谷を含む地表面 态答の絶対值を示している。変位勾配の犬きな箇所や上 下方向の忘答においては、空間離散化の影響や深さ方向 の有限な領域長等に起因すると考えられる若干の差異が 見られるが、本解析モデルによる結果はいずれもLucoら の結果と良い対応を示していることがわかる。

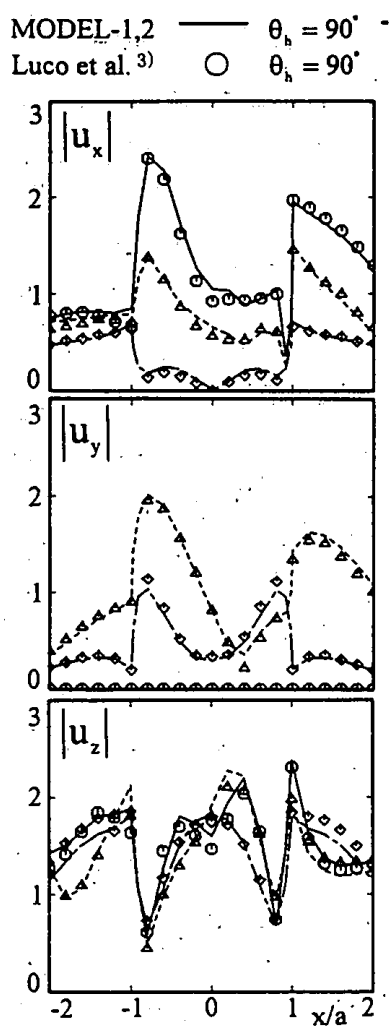

(a) MODEL-1

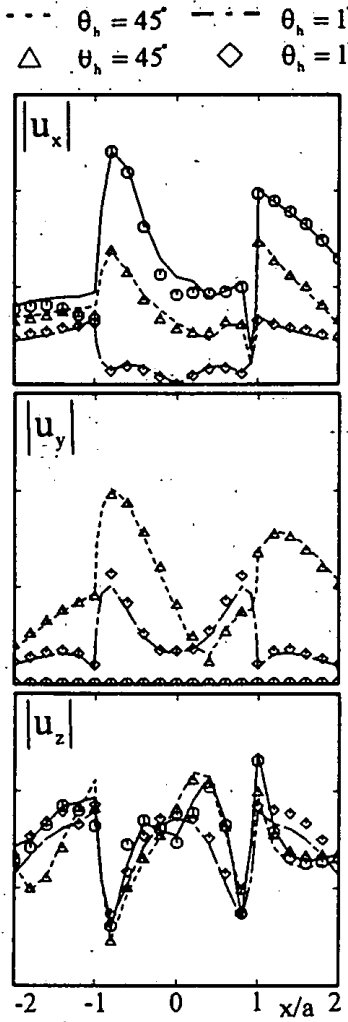

(b) MODEL-2
Fig. 5 Comparison of canyon responses

\section{2 次元堆積谷における波動伝播性状の検討}

Fig.6に示すような 2 次元形状の堆積谷地形（以降、堆 積盆地と表現する。）に対し入射角、方位角を有する平 面実体波が入射するときの波動伝播特性を検討する。

厚さ $400 \mathrm{~m}$ の堆積層の地盤物性は Vs $=500 \mathrm{~m} / \mathrm{s}$ 、 $\mathrm{Vp}=1000 \mathrm{~m} / \mathrm{s} 、 \gamma=2.0 \mathrm{t} / \mathrm{m}^{3} 、 \mathrm{~h}=0.01$ 、半無限地盤の物性は $\mathrm{Vs}=1300 \mathrm{~m} / \mathrm{s} 、 \mathrm{Vp}=2600 \mathrm{~m} / \mathrm{s} 、 \quad \gamma=2.3 \mathrm{t} / \mathrm{m}^{3} 、 \mathrm{~h}=0.005$ でイン ピーダンス比は約2である。解析では 3 つのhyperelement で水平方向の領域をモデル化しており、深さ方向の薄層 要素モデルは全ての領域に対して $40 \mathrm{~m}$ の層を 10 層、 $130 \mathrm{~m}$ の層を10層、最下層にせん断波波長の 1.5 倍を 25 分割した 層構造より構成されている。堆積層部分の表面波基本 モードの位相速度、群速度の分散曲線をFig.7に示す。同 図には薄層要素法、理論解によって得られた表面波の分 散曲線を示しているが、再者は良く一致しており、薄層
モデルの妥当性を示している。

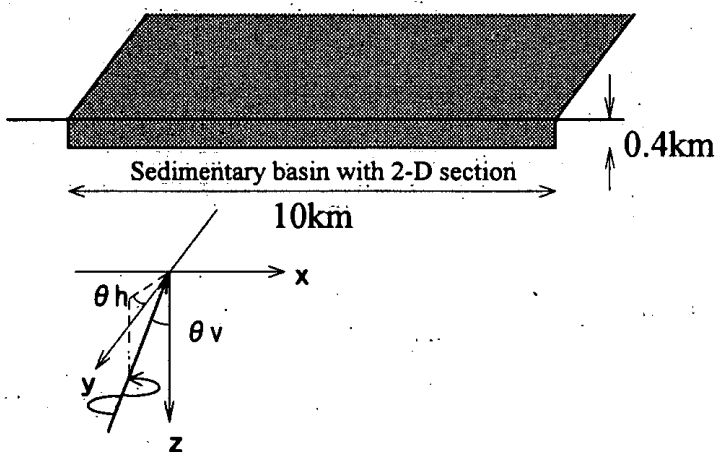

Fig.6 Sedimentary basin subjécted to obliquely incident wave

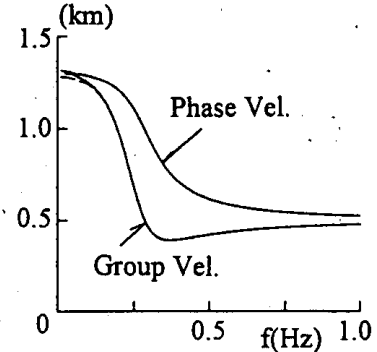

(a) Love wave

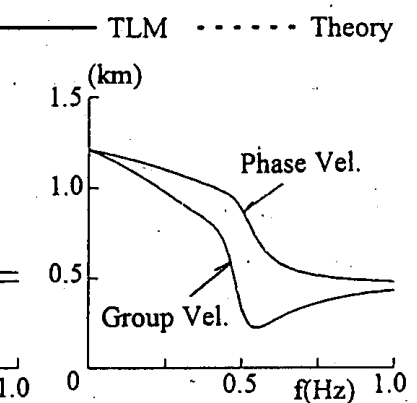

(b) Rayleigh wave
Fig.7 Dispersion curves of fundamental modes of surface waves

入射波の時刻歴波形としてRicker waveletを用い、その 中心周期は堆橨層部のラブ波基本モードのAiry相に相当 する3.2秒とする。応答計算は振動数領域で $1.5 \mathrm{~Hz}$ まで行 い、地震态答はFFTを用いて時間領域への変換を行う。

解析結果の一例としてSH波入射で入射角 $\theta_{v}$ を $20^{\circ}$ に固 定し、方位角 $\theta_{\mathrm{h}}$ を $90^{\circ}, 45^{\circ}, 0^{\circ}$ とした 3 ケースの忘答結果 を示す。Fig.8はy方向の、Fig.9,10はx,y,z方向のy=0断面に おける盆地部と盆地両端の地表面での忘答波形を示した ものである。入射波は、盆地左側端部下位固で規定して いる。また(4a)式において右辺第 1 項を入射場の応答、 鉛直境界からの散乱場応答のうち第 2 、第 3 項目を面外 波動場における応答、第 4 、第 5 項目を面内波動場にお ける応答として分離したときの、面外波動場における応

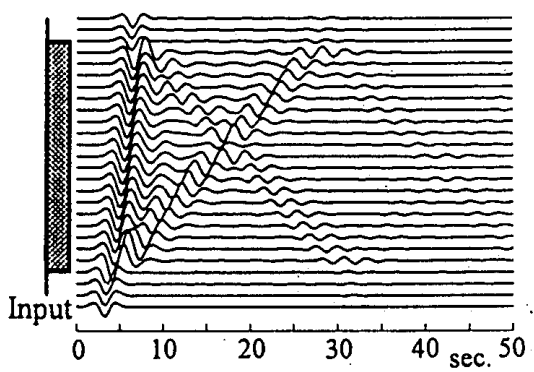

Fig. 8 Displacement waveforms in y-direction across a 2-D basin at $\mathrm{y}=0$ (Incident SH wave with $\theta_{\mathrm{v}}=20^{\circ}, \theta_{\mathrm{h}}=90^{\circ}$ ) 


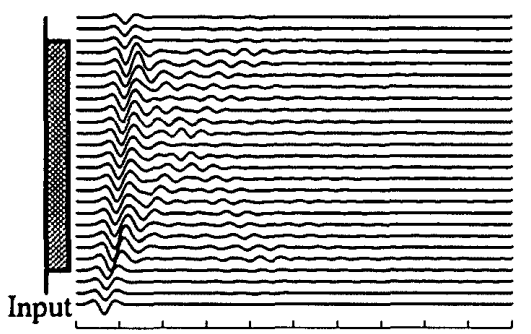

(a) $\mathrm{x}$-direction (total motion)

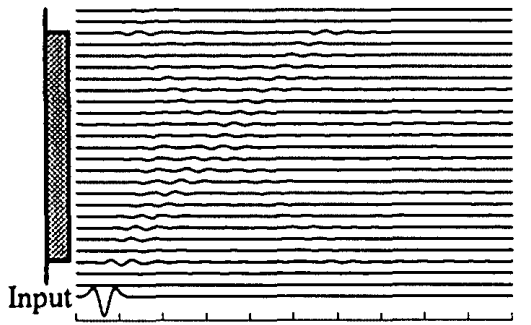

(d) $x$-direction (anti-plane motion)

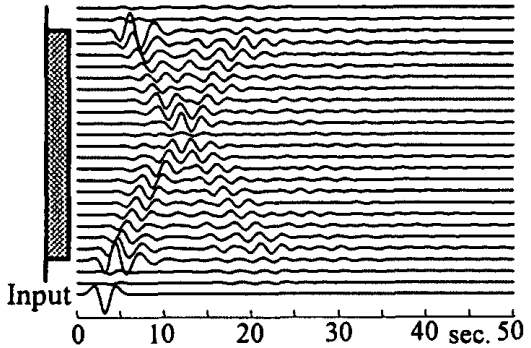

(g) $\mathrm{x}$-direction (in-plane motion)

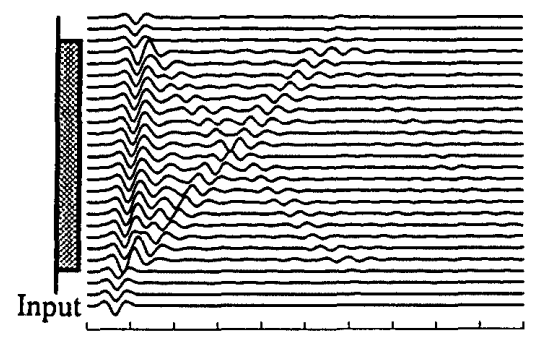

(b) y-direction (total motion)

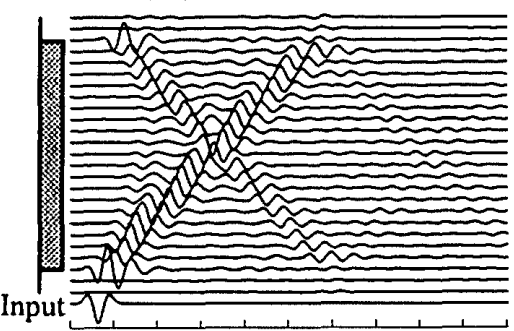

(e) y-direction (anti-plane motion)

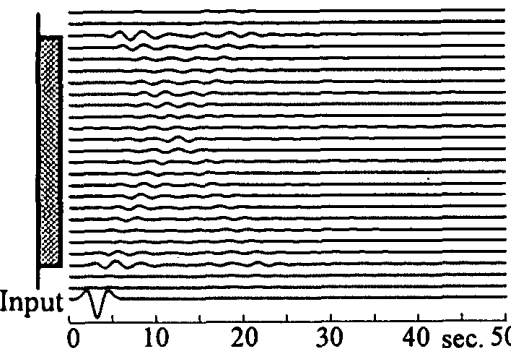

(h) y-direction (in-plane motion)

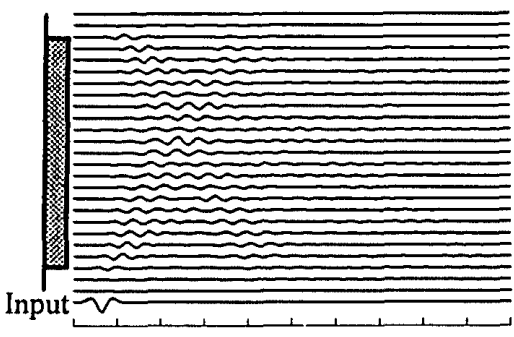

(c) z-direction (total motion)

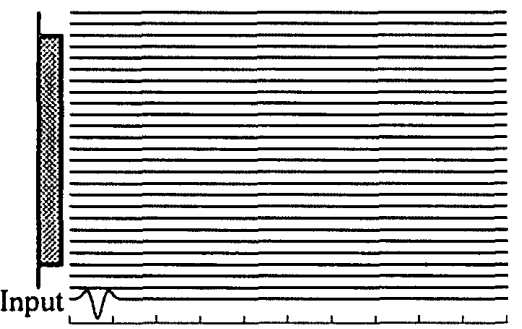

(f) z-direction (anti-plane motion)

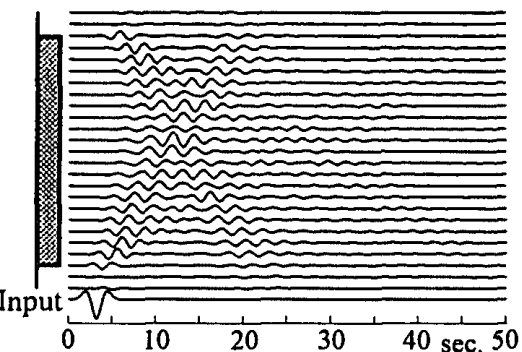

(i) z-direction (in-plane motion)

Fig.9 Displacement waveforms across a 2-D basin at $y=0 \quad$ (Incident SH wave with $\theta_{v}=20^{\circ}$ and $\theta_{h}=45^{\circ}$ )

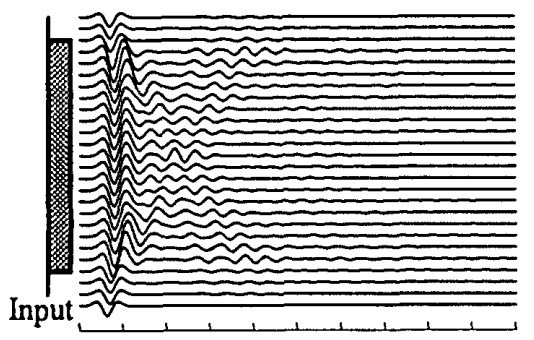

(a) $x$-direction (total motion)

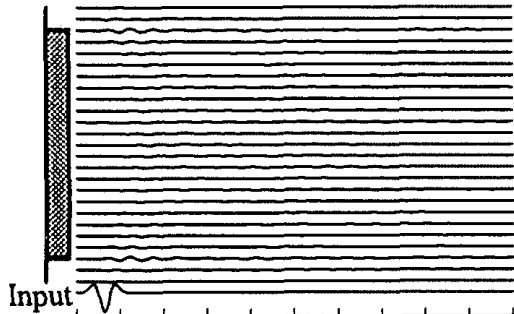

(d) $x$-direction (anti-plane motion)

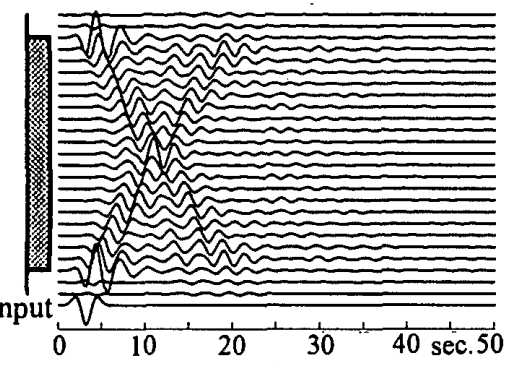

(g) $x$-direction (in-plane motion)

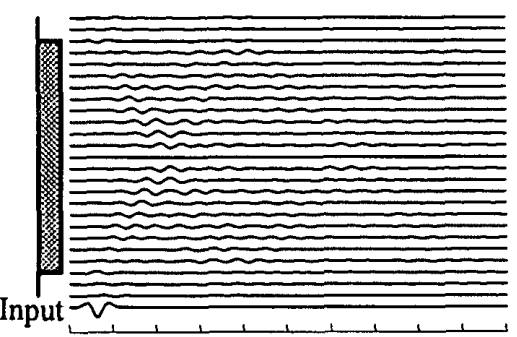

(b) y-direction (total motion)

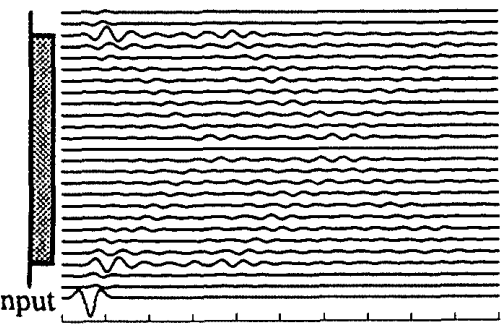

(e) y-direction (anti-plane motion)

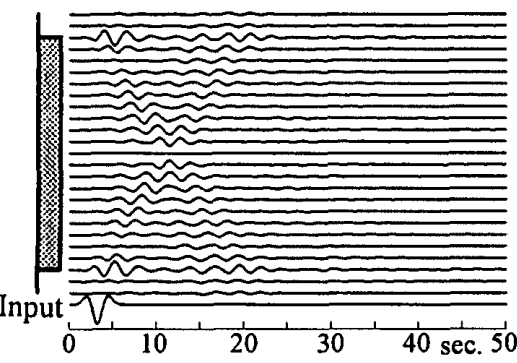

(h) y-direction (in-plane motion)

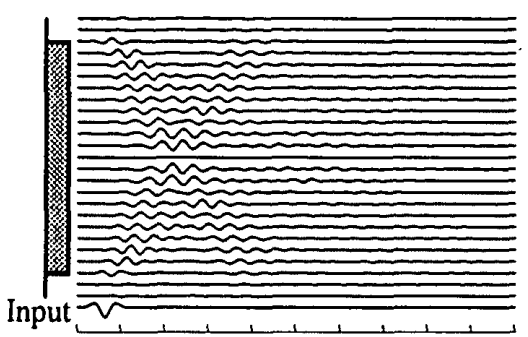

(c) z-direction (total motion)

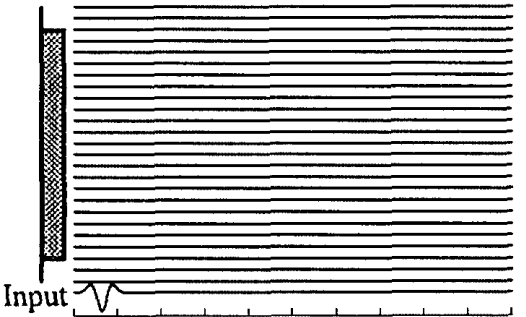

(f) z-direction (anti-plane motion)

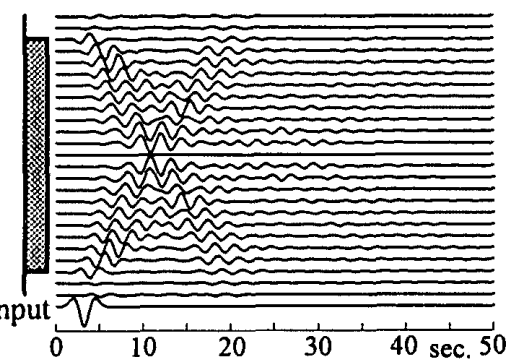

(i) $z$-direction (in-plane motion)

Fig. 10 Displacement waveforms across a 2-D basin at $\mathrm{y}=0 \quad$ (Incident SH wave with $\theta_{\mathrm{v}}=20^{\circ}$ and $\theta_{\mathrm{h}}=0^{\circ}$ ) 
答、面内波動場における态答をFig.9、10に併せて示して いる。ただし分離された散乱応答波形の振幅は全応答波 形の振幅の 2 倍のスケールで示している。

Fig.8の方位角 $\theta_{\mathrm{h}}=90^{\circ}$ のケースは 2 次元面外波動伝播問 題であり、実体波入射後に盆地端部からラブ波を含む面 外波が発生し、反対方向の盆地端部人向かって伝播して いき、再び盆地端部で反射するという盆地構造の面外波 動伝播解析でよく見られる現象が現れている。

一方、Fig. 9 の方位角 $\theta_{\mathrm{h}}=45^{\circ}$ のケースでは 3 次元応答と なり、実体波入射時に盆地端部よりラブ波のみならず、 レイリー波を含む面内波も発生している様子が明らかに 現れている。またラブ波で代表される面外波動成分はy 方向の応答が、レイリ一波で代表される面内波動成分で はx,z方向の応答が優勢であるが、それぞれx方向、y方向 にも連成した応答が現れていることがわかる。これは奥 行き方向の一定速度の波動伝播を考慮するために、 $\mathrm{x}$ 方 向とy方向の答が連成した形となるためである。(2)式 に示すように振動数領域のある波数に対してはこの連成 挙動はある水平角度で分離可能であるが、振動数毎にこ の角度が変化するため時間領域での分離は不可能である。 次にFig.10の $\theta_{\mathrm{h}}=0^{\circ}$ のケースでは入射SH波がy軸方向に 伝播していく形となり、x,z投影面では見かけ上鉛直 $\mathrm{SV}$ 波入射の形となっている。それゆえに波動伝播特性は鉛 直SV波入射時の性質を帯ひ、盆地端部から発生する表面 波は面内波が優勢ではあるが、y方向に一定の速度の波 動場が生じるためにラブ波も同時に発生している。 Fig.10(e)の面外波成分に注目してみると、盆地端部に入 射SH波が入射しラブ波が発生しているが、このラブ波の 波群が反対側の盆地端部に到達する前に、20秒あたりで 別のラブ波の相が盆地端部から発生していることがわか る。これは入射SH波によって盆地端部に生じたレイリー 波が反対側の盆地端部に到達する時刻とほほ一致してい ることから、ラブ波が反対側の盆地端部に到達する前に、 レイリー波からラブ波への表面波の変換が盆地端部で発 生しているものと考えられる。またFig. 9 の $\theta_{\mathrm{h}}=45^{\circ}$ のケー スでも $\theta_{\mathrm{h}}=0^{\circ}$ のケースほど明瞭ではないが、30秒前後で 反対にラブ波からレイリー波の変換が発生している。一 般的にこの表面波の変換に関してはレイリー波からラブ 波、その逆のパターンの他、本解析ケースのような鉛直 境界での反射のみでなく、逆に表面波が堆積層へ透過す るときに発生する変換も考えらる。すなわち現象として は、異なる物性を有する層に斜めから入射してくるSV波 が反射 SV波、反射P波、透過 SV波、透過P波となる現象 に類似している。ただしその反射、透過の大小関係につ いては、平面波の反射・透過とは異なり、領域の層構成、 方位角、振動数等の条件によって複雑に変化するものと 考えられる。ここではSV波入射時、表面波入射時の結果
は省略するが、水平方向の連成挙動や鉛直境界での表面 波変換については同様の現象が見られている。

\section{5. 半無限地盤中の双設トンネルの地震応答解析}

既往の研究では方位角を有する入射波に対し単独トン ネルを対象とした解析 ${ }^{4)}$ や、双設トンネルの 2 次元解析 ${ }^{13)}$ は実施されているが、方位角を有する斜め入射波に対す る双設トンネルの 3 次元解析例はあまり見られない。そ こで半無限地盤中の双設トンネルについて、斜め入射角、 方位角を有する平面波入射に対する 3 次元忘答解析を行 う。このときトンネルの半径 $\mathrm{r}=5 \mathrm{~m}$ 、厚さ $\mathrm{t}=0.5 \mathrm{~m}$ 、地表面 からトンネルの中心点までの深さ $\mathrm{H}=15 \mathrm{~m}$ 、半無限地盤の せん断波速度 Vs $=200 \mathrm{~m} / \mathrm{s}$ 、ポアンン比 0.4 、単位体積重量 $2.0 \mathrm{t} / \mathrm{m}^{3}$ 、减衰定数 $1 \%$ とし、SV波入射時を対象とする。 入射角 $\theta_{\mathrm{v}}$ 、方位角 $\theta_{\mathrm{h}}$ 、トンネル間隔Lを変化させたパラ メータ解析を実施し、同じ条件で単独トンネルの态答と 比較することによってその周波数応答性状を検討する。 解析モデルはFig.11に示すように、トンネル部とその周 囲を有限要素で、トンネル間領域や左右無限領域等は hyperelementでモデル化する。トンネル部は 1 層28個の 4 節点アイソパラメトリック要素でモデル化し、その材料 定数はヤング率 $2.7 \times 10^{6} \mathrm{t} / \mathrm{m}^{2}$ 、ポアソン比 0.167 、単位体 積重量 $2.5 \mathrm{t} / \mathrm{m}^{3}$ 、减衰定数 $0 \%$ とする。

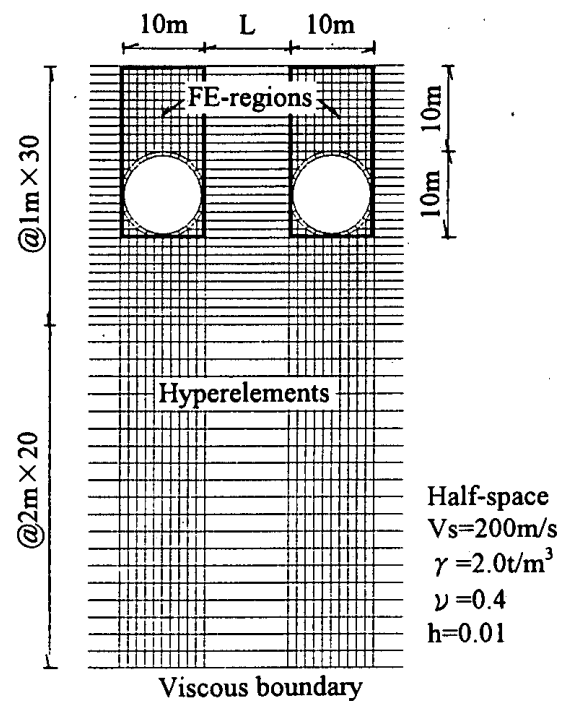

Fig. 11 Modelling of twin tunnels embedded in a half-space

最初にトンネル間隔Lを $10 \mathrm{~m} に$ 固定して、入射角 $\theta_{v} 、$ 方 位角 $\theta_{\mathrm{h}}$ を变化させたときの応答結果を示す。解析ケース は (a) $\theta_{v}=0^{\circ}, \theta_{\mathrm{h}}=90^{\circ} 、$ (b) $\theta_{\mathrm{v}}=20^{\circ}, \theta_{\mathrm{h}}=90^{\circ} 、$ (c) $\theta_{\mathrm{v}}=20^{\circ}$, $\theta_{\mathrm{h}}=45^{\circ}$ 、(d) $\theta_{\mathrm{v}}=20^{\circ}, \theta_{\mathrm{h}}=0^{\circ}$ の 4 ケースとする。このとき (a)(b)のケースは 2 次元面内問題となる。ここでは応答変 位結果のみを示すが、态力に関してもその周波数応答性 

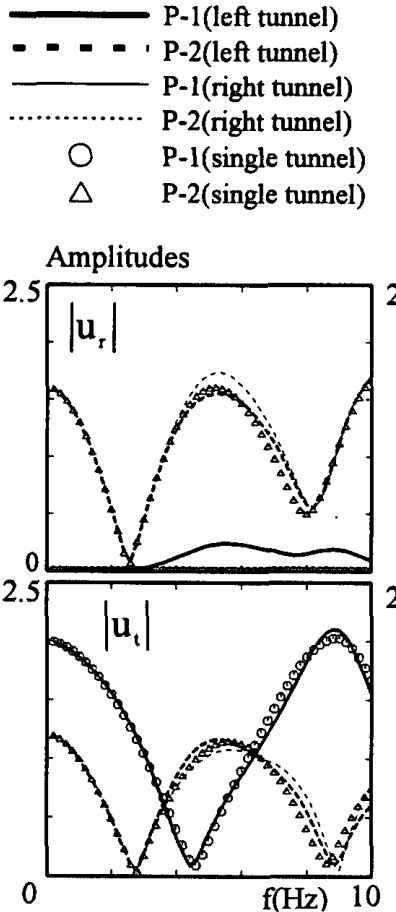

(a) $\theta_{v}=0^{\circ}, \theta_{\mathrm{h}}=90^{\circ}$

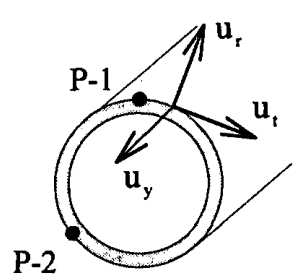

Amplitudes

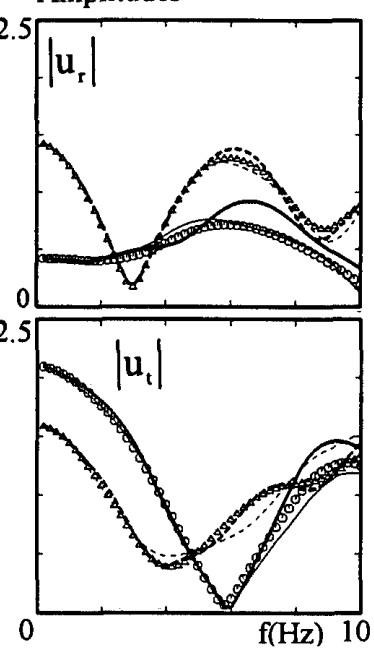

(b) $\theta_{v}=20^{\circ}, \theta_{\mathrm{h}}=90^{\circ}$

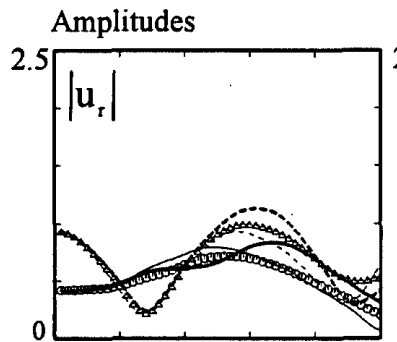

Amplitudes
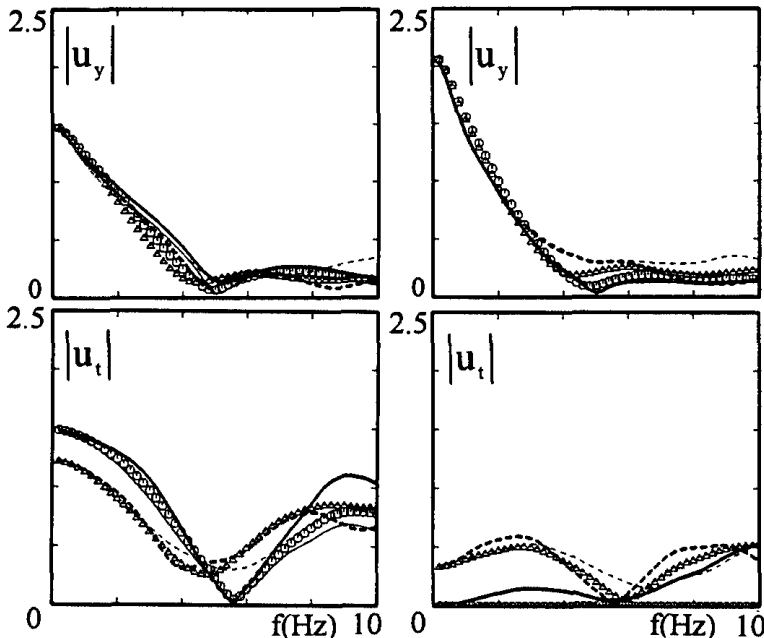

(c) $\theta_{v}=20^{\circ}, \theta_{\mathrm{h}}=45^{\circ}$

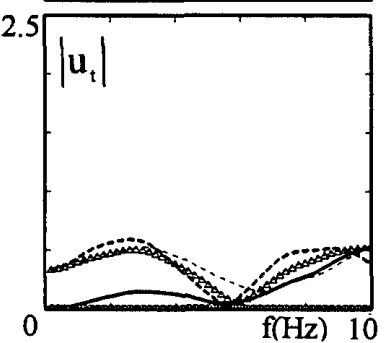

(d) $\theta_{v}=20^{\circ}, \theta_{\mathrm{h}}=0^{\circ}$

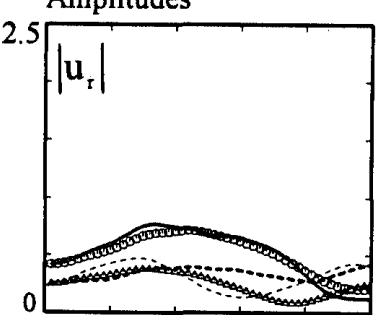

Fig. 12 Displacement amplitudes at surface points of twin tunnels
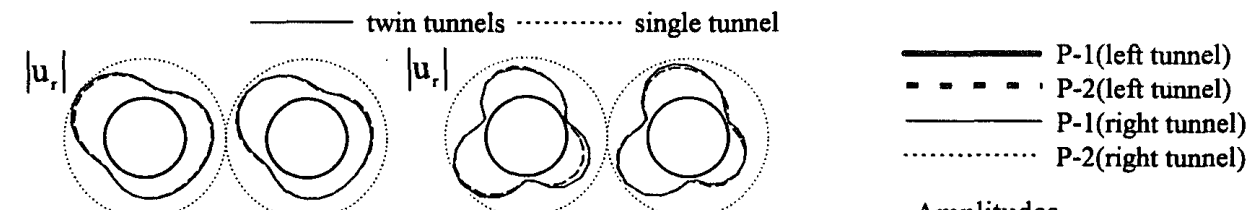

P-l(single tunnel)

$\triangle \quad$ P-2(single tunnel)

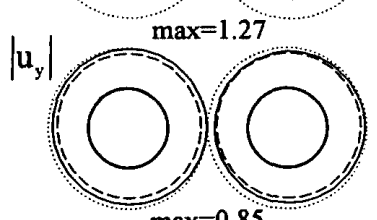

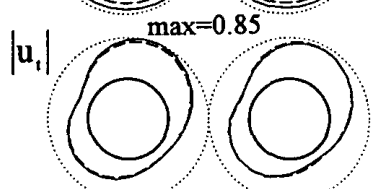

$\max =1.26$

(a) $\mathrm{f}=2.5 \mathrm{~Hz}$ $\left|\mathbf{u}_{\mathbf{y}}\right|$

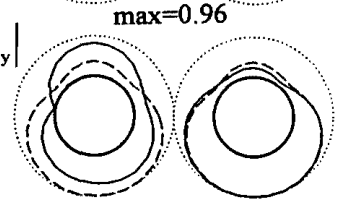

$\left|u_{t}\right|$

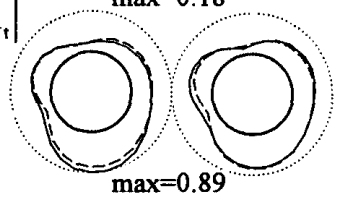

(b) $\mathrm{f}=5.0 \mathrm{~Hz}$

$\left|u_{r}\right|$

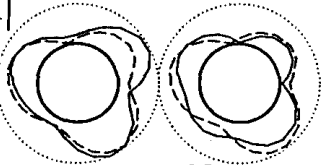

$\max =1.35$

$\left|\mathbf{u}_{\mathrm{y}}\right|$
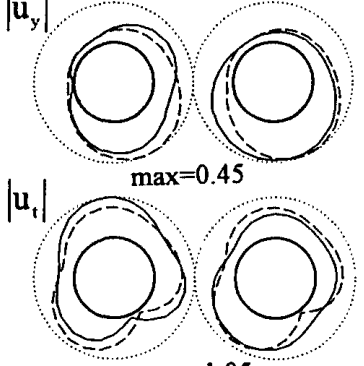

$\max =1.05$

(d) $\mathrm{f}=10.0 \mathrm{~Hz}$ $\begin{aligned} & \max =0.98 \\ & \text { (c) } \mathrm{f}=7.5 \mathrm{~Hz}\end{aligned}$
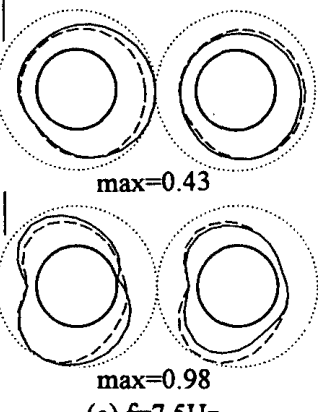

$\left|\mathbf{u}_{\mathrm{t}}\right|$

Fig. 13 Distribution of displacement at surface points of twin tunnels

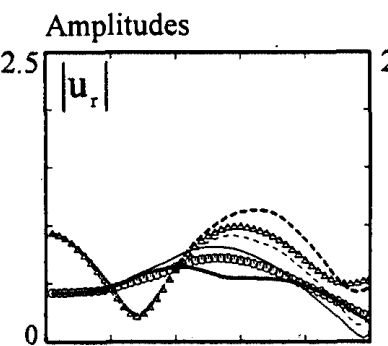

Amplitudes
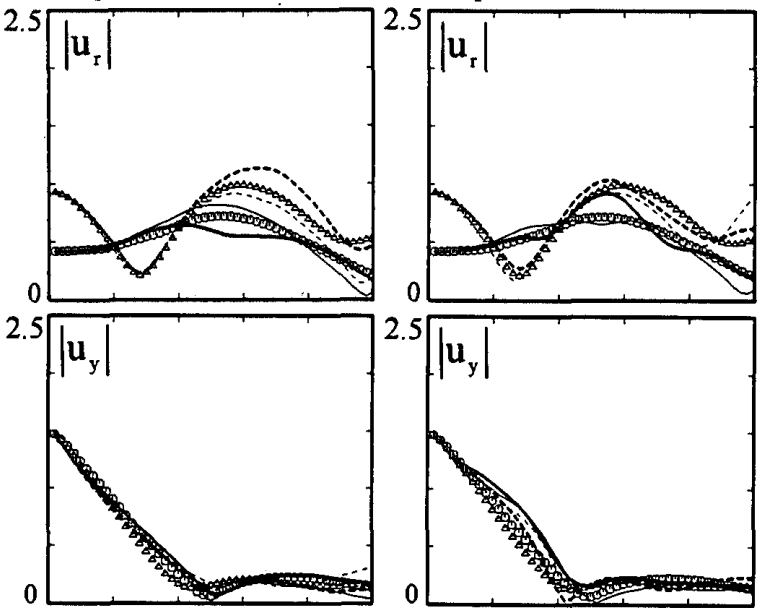

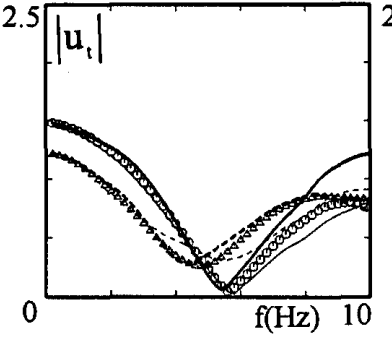

(a) $\mathrm{L}=5 \mathrm{~m}$

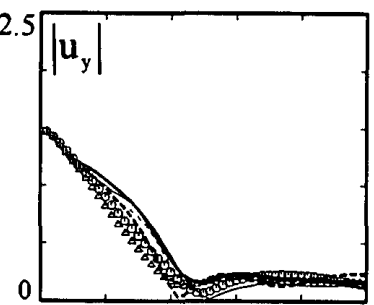

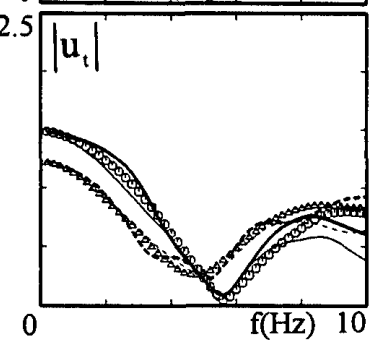

(b) $\mathrm{L}=20 \mathrm{~m}$

Fig.14 Displacement amplitudes at surface points of twin tunnels with various spacings 
状は変位と同様の傾向を示している。Fig.12は 4 解析 ケースに対して左右トンネルの外周 2 点における 3 方向 の応答変位、才なわち半径方向 $\mathbf{u}_{\mathrm{r}}$ 、奥行方向 $\mathbf{u}_{\mathrm{y}}$ 、円周方 向 $\mathrm{u}_{\mathrm{t}}$ の忘答変位の絶対値を振動数 $10 \mathrm{~Hz}$ までに対して示し たものであり、単独トンネルの态答も比較して示してい る。入射波規定位置は双設トンネル間中央の地表面とし、 半無限地盤における入射波の振幅に対する值として示し ている。また、Fig.13は、(c) $\theta_{\mathrm{r}}=20^{\circ}, \theta_{\mathrm{h}}=45^{\circ}$ の解析結果の うち 4 振動数 $(2.5,5.0,7.5,10.0 \mathrm{~Hz})$ を対象として、态答変 位 3 成分の絶対值振幅分布を各トンネルの円周方向にお ける位直から放射状に示している。忘答振幅は各図に示 されている最大值で規淮化されている。

鉛直入射となる(a)のケースでは、双設トンネルと単独 トンネルの挙動の差異はほとんど見られないが、2次元 斜め入射となる(b)のケースでは $5 \mathrm{~Hz}$ を越えたあたりから 左右のトンネルの挙動に差異が現れてくる。特に入射波 に対し前面側となる左側の応答が右側に比べ大きくなっ ており、いわゆる shadow効果が現れている。周波数特性 はトンネル該当位直から上の地盤の固有振動特性に影響 を受けており、モードの節、腹が明瞭に現れている。 (c)(d)のケースは 3 次元忘答となり、奥行き方向となるy 方向にも态答が現れる。(c)のケースでは(b)のケースと同 様に半径方向、円周方向にshadow効果が現れ、その効果 は 2 次元の(b)のケースに比べ若干大きい。一方、奥行き 方向の応答には双設トンネルの影響はあまり影著には現 れず、双設トンネル、単独トンネルとも同様な挙動を示 す。特に低振動数域ではFig.13(a)に示すように、振幅分 布は同心円状となっている。また(d)のケースでは入射が 見かけ上 $\mathrm{SH}$ 波入射となり、その応答も鉛直 $\mathrm{SH}$ 波入射 時の性質を帯びてくる。しかし面内方向（r,t方向）にも 比較的大きな応答振幅が現れ、方位角入射による3次元 効果が大きいことが分かる。双設トンネルと単独トンネ ルの态答比較では奥行き方向に比へ、面内方向に差異が 若干大きく現れてくる。Fig.13の応答振幅分布では振動 数によって分布性状が大きく変化すること、振動数が高 くなるにつれて双設トンネルと単独トンネルの応答の差 異が大きくなり、shadow効果により左側のトンネルの态 答変位分布が若干大きくなっていることが分かる。

次に入射角 $\theta_{v}$ を $20^{\circ}$ 、方位角 $\theta_{\mathrm{h}}$ を $45^{\circ}$ に固定して、トン ネル間隔 Lを(a) $5 \mathrm{~m} 、(\mathrm{~b}) 20 \mathrm{~m}$ と変化させたときの忘答結果 をFig.13に示す。Fig.12(c)と同様に双設トンネルの面内方 向の忘答には相互作用の影響が高振動数域で現れ、トン ネル間隔が短くなるほどその効果が大きくなる傾向にあ

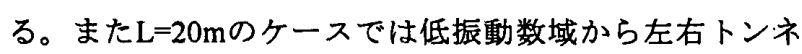
ルの振幅に若干の差異が現れるが、これはトンネル間隔 が長くなり、低振動数域で地盤のせん断波長によるモ一 ド長と合致したために、左右トンネルの応答に影響を及 ぼしたものと考えられる。奥行き方向のy方向では前解 析ケースと同様に双設トンネルによる相互作用の影響は 小さい。

以上の応答結果は非常に限られた解析ケースでの結果 であり、その応答性状は入射波、入射角、振動数だけで はなく、トンネルの大きさ、地盤の物性、深さ等によっ ても大きく変化する。また方位角を有する入射波に対し ては、その态答が 3 次元となり、考慮する态力も 6 成分 となるので、設計時に地震応答解析を行うときは個々の ケースに忘じた応力評価が必要であろう。

\section{6.まとめ}

斜め入射波が方位角を有する場合の 2 次元構造物の 3 次元応答解析に対して、移動荷重に対するhyperelementや 有限要素との結合による解析手法を示し、その適用例と して 2 次元堆積谷地形における 3 次元波動伝播解析、半 無限地盤中の双設トンネルの実体波斜め入射時の応答解 析を示した。前者に関しては、大領域構造における波動 伝播解析手法の 1 つとしてhyperelementを用いた手法の有 用性を示した。また 3 次元波動伝播特性として堆積地盤 での面外波、面内波の連成挙動や、鉛直地層境界でのレ イリー波からラブ波への表面波の変換を確認することが できた。後者に関しては、単独トンネルとの比較により、 shadow効果等の双設トンネルの複雑な 3 次元応答特性が 示された。

いずれの 3 次元応答も通常の面内 - 面外 2 次元解析、 もしくはその組み合わせのみでは表現できない忘答特性 を示しており、以上のような 3 次元応答解析が今後も重 要となるものと考えられる。またhyperelementと有限要素 とを組み合わることにより、複雑な地層構成を有する構 造や、トンネル構造以外にもパイプライン、共同漬など その断面寸法に対し奥行き方向が比較的長い土木構造物 など、各種 2 次元構造物のモデル化が可能であり、これ らの 3 次元応答解析手法として幅広い忘用が期待できる。

\section{磾辞}

本研究はKAJMA/CUREe プロジェクトの1つである「Seismic Response of Underground Structures in Soft Soil」を契機として実施した ものであり、鹿島技術研究所、大保直人博士をはじめとする関保各 位に感謝いたします。また本研究を進めるに当たり御協力頂きました 鹿島小腒研究室、釜田 正敖氏に感即いたします。

考文献

1) Kausel,E. and Roesset,J.M. : Semianalytic Hyperelement for Layered Strata, J.Engrg.Mech, ASCE, 103(4), pp.569-588, 1977

2) Wong,K.C., Datta,S.K. and Shah,A.H. : Three-Dimensional Motion of Buried Pipeline, J. Engrg. Mech., ASCE, 112(12), pp. 1319-1337, 1986

3) Luco,J.E., Wong,H.L. and Barros,F.C.P. : Three-Dimensional Response of a Cylindrical Canyon in a Layered Half-Space, Earthquake eng. struct. dyn. 19, pp.799-817, 1990

4) Luco,J.E. and Barros,F.C.P. : Seismic Response of a Cylindrical Shell Embedded in a Layered Viscoelastic Half-Space, Earthquake eng. struct. 
dyn. 23, pp.553-580, 1994

5) Khair,K.R., Datta,S.K. and Shah,A.H. : Ampilification of Obliquely Incident Seismic Waves by Cylindrical Alluvial Valleys of Arbitrary Cross-Sectional Shape. Part I. Incident P and SV Waves, Bull. Seism. Soc. Am., 79(3), pp.610-630, 1989

6) Liu,S.W., Datta,S.K., Khair,K.R. and Shah,A.H. : Three Dimensional Dynamics of Pipelines Buried in Backfilled Trenches due to Oblique Incident of Body Waves, Soil dyn. earthquake eng. 10, pp.182-191, 1991

7) 福和伸夫, 梅村健次, 多賀直恒 : 等速移動点加振力に対する 3 次 元均質等方弾性体の基本解に関寸る研究，日本建築学会㭢造系論 文報告集，第441号，pp.45 52, 1992

8）福和伸夫ほか 4 名：自動車走行外乱による地盤の振動性状に関す る研究一実測記録の分析と薄層法によるシミュレーション解析一 構造工学論文集, Vol.39B、pp.95〜104, 1993

9）源栄正人、菅原 長、永野正行： 3 炊元成畨地盤におけるMoving Green's Functionの基本的榆郡，日本建築学会構造系論女報告集， 第462号, pp.51 60, 1994

10) Hwang,R.N. and Lysmer,J. : Response of Buried Structures to Traveling Waves, J. Geotech. Engrg., ASCE, 107(8), pp.183-200, 1981

11) Hanazato, $T$, Ugai, $K$, Mori, $M$ and Sakaguchi, $R$ : Three-Dimensional Analysis of Traffic-Induced Ground Vibrations, J. Geotech. Engrg., ASCE, 117(8), pp.1133-1151, 1991

12) 前田 寿郎：面内問題における半無限体近似インピータンスの検 討, 日本建学会大会㩐造系論文報告集, 第442号, pp.61 70, 1992

13) Takemiya, H. and Wang, H. : Seismic Responses of Tunnels Buried in a Layered Half Space, Proc. of the 9th Japan Earthquake Engineering Symposium, Vol.2, 1267-1272, 1994

\section{APPENDIX- I}

(3)式中のマトリックスについて

$\left[\mathrm{A}_{\mathrm{s}}\right]^{\mathrm{e}}=\frac{\mu \mathrm{H}}{6}\left[\begin{array}{cc}2 & 1 \\ 1 & 2\end{array}\right]^{\circ},\left[\mathrm{A}_{\mathrm{P}}\right]^{\mathrm{e}}=\frac{(\lambda+2 \mu) \mathrm{H}}{6}\left[\begin{array}{ll}2 & 1 \\ 1 & 2\end{array}\right]$
$\left[\mathrm{E}_{\mathrm{s}}\right]^{\circ}=\frac{\mu}{\mathrm{H}}\left[\begin{array}{cc}1 & -1 \\ -1 & 1\end{array}\right]-\omega^{2}\left[\mathrm{M}_{\mathrm{s}}\right]^{e},\left[\mathrm{E}_{\mathrm{p}}\right]^{\circ}=\frac{(\lambda+2 \mu)}{\mathrm{H}}\left[\begin{array}{cc}1 & -1 \\ -1 & 1\end{array}\right]-\omega^{2}\left[\mathrm{M}_{\mathrm{s}}\right]^{\circ}$
$[\mathrm{B}]^{\mathrm{e}}=\left[\begin{array}{cc}(\lambda-\mu) / 2 & (\lambda+\mu) / 2 \\ -(\lambda+\mu) / 2 & -(\lambda-\mu) / 2\end{array}\right],\left[\mathrm{M}_{\mathrm{s}}\right]^{e}=\frac{\rho \mathrm{H}}{6}\left[\begin{array}{cc}2 & 1 \\ 1 & 2\end{array}\right]$

$E_{s}^{\prime}(N, N)=i \omega \rho_{N} V_{S N} \quad, \quad E_{p}^{\prime}(N, N)=i \omega \rho_{\mathrm{s}} V_{P N}$

上添字 $\mathrm{e}$ は 1 層分の薄層要菜の剛性を示し、Hは薄層要素の厚さを示す。

\section{APPENDIX-II}

(5)式中のマトリックスについて

$[A]=\left[\begin{array}{ccc}{\left[A_{p}\right]} & {[0]} & {[0]} \\ {[0]} & {\left[A_{s}\right]} & {[0]} \\ {[0]} & {[0]} & {\left[A_{s}\right]}\end{array}\right],[G]=\left[\begin{array}{ccc}{[0]} & {\left[A_{P}\right]-2\left[A_{s}\right]} & {[0]} \\ {\left[A_{s}\right]} & {[0]} & {[0]} \\ {[0]} & {[0]} & {[0]}\end{array}\right]$

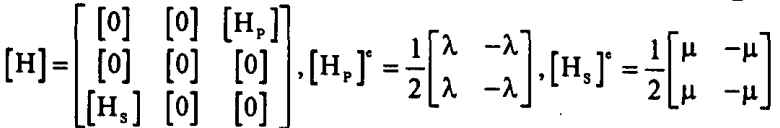

\section{APPENDIX-III}

(11)式中の自由地盤応答の算定

$\left(\mathbf{k}_{x}^{2}\left[A_{\mathrm{P}}\right]+\left[\mathrm{E}_{\mathrm{s}}\right]+\left[\mathrm{I}_{11}\right]\right)\left\{\mathrm{U}_{1}^{\mathrm{t}}\right\}+\left(-\mathrm{ik}_{\times}[\mathrm{B}]^{\mathrm{T}}+\left[\mathrm{I}_{12}\right]\right)\left\{\mathrm{U}_{2}^{\mathrm{t}}\right\}=\left\{\mathrm{D}_{1}\right\}$

$\left(\mathrm{k}_{\mathrm{x}}^{2}\left[\mathrm{~A}_{\mathrm{s}}\right]+\left[\mathrm{E}_{\mathrm{p}}\right]+\left[\mathrm{I}_{22}\right]\right)\left\{\mathrm{U}_{2}^{\mathrm{\prime}}\right\}+\left(\mathrm{ik}_{\mathrm{x}}[\mathrm{B}]+\left[\mathrm{I}_{21}\right]\right)\left\{\mathrm{U}_{1}^{\prime}\right\}=\left\{\mathrm{D}_{2}\right\}$

$\left(\mathbf{k}_{x}^{2}\left[\mathrm{~A}_{3}\right]+\left[\mathrm{E}_{3}\right]+\left[\mathrm{I}_{33}\right]\right)\left\{\mathrm{U}_{3}^{\mathrm{r}}\right\}=\left\{\mathrm{D}_{3}\right\}$

$I_{11}(N, N)=c_{1} \eta_{p}, I_{12}(N, N)=-c_{1} k_{x^{\prime}}+c_{2}$

$I_{21}(N, N)=c_{1} k_{x^{\prime}}-c_{2}, I_{22}(N, N)=c_{1} \eta_{s}$

$I_{33}(N, N)=i \mu_{N} \eta_{s}$

$D_{1}(N)=c_{1} \eta_{P} \widetilde{U}_{1}^{\prime}, D_{2}(N)=c_{1} \eta_{s} \widetilde{U}_{2}^{\prime}, D_{3}(N)=i \mu_{N} \eta_{s} \cdot 2 U_{0}^{s H}$

$c_{1}=i \omega^{2} \rho_{N} /\left(k_{x^{\prime}}^{2}+\eta_{P} \eta_{s}\right), c_{2}=2 i \mu_{N} k_{x}$
$\left\{\begin{array}{c}\tilde{U}_{1}^{r} \\ \tilde{U}_{2}^{r}\end{array}\right\}=\left\{\begin{array}{c}-\frac{\eta_{\mathrm{s}} \mathrm{V}_{\mathrm{SN}}}{\omega} \\ -\frac{\mathbf{k}_{\mathrm{x}^{\prime}} \mathrm{V}_{\mathrm{SN}}}{\omega}\end{array}\right\} \cdot 2 \mathrm{U}_{0}^{\mathrm{SV}},\left\{\begin{array}{c}-\frac{\mathbf{k}_{\mathrm{x}^{\prime}} \mathrm{V}_{\mathrm{PN}}}{\omega} \\ \frac{\eta_{\mathrm{P}} \mathrm{V}_{\mathrm{PN}}}{\omega}\end{array}\right\} \cdot 2 \mathrm{U}_{0}^{\mathrm{P}}$

(SV-wave) (P-wave)

$\frac{\omega^{2}}{\mathrm{~V}_{\mathrm{gN}}^{2}}-\eta_{\mathrm{s}}^{2}=\frac{\omega^{2}}{\mathrm{~V}_{\mathrm{PN}}^{2}}-\eta_{\mathrm{p}}^{2}=\mathrm{k}_{\mathrm{x}^{\prime}}^{2}$

$\mathrm{U}_{0}^{\mathrm{SH}}, \mathrm{U}_{0}^{\mathrm{SV}}, \mathrm{U}_{0}^{\mathrm{P}}$ はそれぞれの入射波の振幅を示す。

\section{APPENDLX-IV}

(15)式中のマトリックス $\left[\mathrm{B}_{\mathrm{F}}\right]$ について

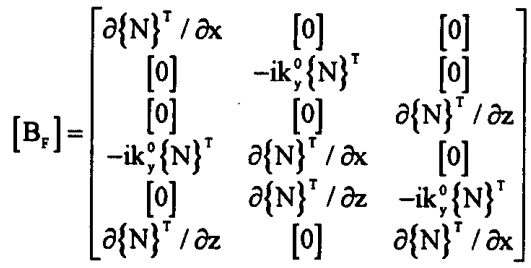

ここで $\{\mathrm{N}\}$ は要菜形状関数から成る 4 次元のベクトルであり、

$\partial\{\mathrm{N}\} / \partial \mathrm{x}, \partial\{\mathrm{N}\} / \partial \mathrm{z}$ はヤコピンマトリックスを用いて求めることが できる。 